\title{
Rhizobium loti, a New Species of Legume Root Nodule Bacteria
}

\author{
B. D. W. JARVIS,${ }^{1}$ C. E. PANKHURST, ${ }^{2}$ AND J. J. PATEL ${ }^{2}$ \\ Department of Microbiology and Genetics, Massey University, ${ }^{1}$ and Applied Biochemistry Division, \\ Department of Scientific and Industrial Research, ${ }^{2}$ Palmerston North, New Zealand
}

\begin{abstract}
Comparative studies of fast-growing Lotus rhizobia were reviewed, and as a result a new species, Rhizobium loti, is proposed. The type strain of this species, which was isolated from a root nodule on Lotus corniculatus (bird's-foot trefoil), is NZP 2213 (= ATCC 33669). Plant specificity, phage relationships, the solubleprotein pattern, and deoxyribonucleic acid base sequence homology distinguished $R$. loti from currently recognized Rhizobium species.
\end{abstract}

Rhizobium species have been defined in terms of plant cross-inoculation groups (16). However, it is generally recognized that this approach is inadequate since cross-inoculation groups are not mutually exclusive $(9,11,31)$ and plant specificity is probably a plasmid-borne character $(4,6,21,29)$. Furthermore, many of the strains studied have never been designated by a species name, including the Lotus rhizobia, which nodulate a variety of leguminous plants belonging to the genera Lupinus, Ornithopus, Anthyllis, Caragana, and Astragalus $(13,14)$.

A revised classification of the genus (D. C. Jordan, personal communication) has been proposed for the forthcoming edition of Bergey's Manual of Determinative Bacteriology, in which the fast-growing species Rhizobium trifolii, Rhizobium phaseoli, and Rhizobium leguminosarum are combined as one species, designated $R$. leguminosarum (Frank) Frank, comprising three biovars (trifolii, phaseoli, and viceae). Rhizobium meliloti Dangeard is retained as a separate species in the genus Rhizobium, and those rhizobia which grow slowly on yeast extract media are transferred to a separate genus, Bradyrhizobium (15). Only one species is recognized in this genus, Bradyrhizobium japonicum (Kirchner) Jordan 1982. As part of this revision it is proposed that the fast-growing Lotus rhizobia and related strains be recognized as a new species, Rhizobium loti.

Two groups of Lotus rhizobia have been recognized in comparative studies of bacteroid ultrastructure (7), internal antigens $(23,32$, extracellular polysaccharide composition (2), enzymatic complement (17-19), gel electrophoresis of soluble proteins $(27,28)$, growth rate and acid production on yeast extract media $(1,5,20)$, susceptibility to flavolans and isoflavonoids (24, 25 ), susceptibility to antibiotics (22), phage relationships (26), deoxyribonucleic acid (DNA) homology $(8,12)$, and plant cross-nodulation $(1,8$,
$10,13,14,22)$. Several of these criteria indicate that the fast-growing, acid-producing Lotus rhizobia are also clearly distinguishable from $R$. leguminosarum and $R$. meliloti $(8,12,18,24,25$, $28,29,32$ ).

Jensen and Hansen $(13,14)$ discovered an extensive cross-inoculation group involving the plant genera Lupinus, Ornithopus, Lotus, Anthyllis, Caragana, Astragalus, Ononis, Genista, and Mimosa, which were nodulated by both fast- and slow-growing rhizobia. Recent DNADNA hybridization studies have shown that fast-growing Lotus rhizobia are genetically related to rhizobia obtained from a variety of plant hosts, including Lotus corniculatus, Lotus divaricatus, Lotus maroccanus, Lotus tenuis, Caragana arborescens, Cicer arietinum, Luecaena leucocephala, Lupinus densiflorus, Onobrychis viciifolia, Parochetus communis, Psoralea eriatha, Robinia pseudoacacia, Sophora angustifolia, Sophora microphylla, Sophora tetraptera, and Trifolium lupinaster (8), as well as Carmichaelia species (12). Consequently, we expect that although the description of $R$. loti given below is based on characteristics of wellstudied root nodule bacteria (Table 1) from Lotus corniculatus and Lotus tenuis, the description probably applies to rhizobia from the wider range of plant species indicated above.

Rhizobium loti sp. nov. (M.L. noun Lotus generic name; M.L. gen. noun loti of Lotus). Short, gram-negative, nonsporeforming rods which are motile predominantly by means of one polar or subpolar flagellum. In nodules the cells are bacteroids (i.e., club shaped and branched) and contain inclusion bodies composed of poly$\beta$-hydroxybutyric acid. Other inclusions, such as polyphosphate bodies, glycogen granules, and lipid droplets, are not present.

Colonies on Vincent yeast mannitol agar (30) are more than $1.0 \mathrm{~mm}$ in diameter after 7 days at $28^{\circ} \mathrm{C}$, but growth is inhibited at $42^{\circ} \mathrm{C}$. Growth at 
TABLE 1. Fast-growing Lotus rhizobia included as members of $R$. loti and references in which these strains are described

\begin{tabular}{|c|c|c|}
\hline Strain $^{a}$ & Reference(s) & $\begin{array}{l}\text { Other sources of } \\
\text { information }^{b}\end{array}$ \\
\hline NZP 2014 & $2,7,23,26$ & Patel; Pankhurst \\
\hline NZP 2024 & $2,7,23$ & Pankhurst \\
\hline NZP 2034 & $2,8,23$ & \\
\hline NZP 2037 & $2,7,8,22,23,26$ & Patel; Pankhurst \\
\hline NZP 2042 & $2,7,23$ & Patel \\
\hline NZP 2048 & $2,7,22,23$ & Patel \\
\hline NZP 2079 & 2,23 & Pankhurst \\
\hline NZP 2985 & $2,7,23$ & \\
\hline NZP 2150 & $2,7,23$ & Pankhurst \\
\hline NZP 2171 & $2,7,23$ & \\
\hline NZP 2196 (= SU343) & $2,7,8,23$ & Patel \\
\hline NZP 2205 & $7,23,26$ & Patel \\
\hline NZP 2213 & $7,8,22,23,26$ & Patel; Pankhurst \\
\hline $\begin{array}{r}\text { NZP } 2227 \text { (= strain } 461 \text {, } \\
\text { University of Guelph) }\end{array}$ & $7,8,23,26$ & Patel \\
\hline NZP $2230(=\mathrm{CC} 809 \mathrm{a})$ & $2,8,23$ & \\
\hline NZP $2234(=$ CC811) & $2,7,23$ & \\
\hline NZP $2235(=$ CC812a) & 23 & Patel \\
\hline NZP $2238(=$ Lc265Da $)$ & $7,8,22,23,26$ & Patel \\
\hline NZP 2260 & $8,23,26$ & Patel \\
\hline
\end{tabular}

${ }^{a}$ NZP, New Zealand Department of Scientific and Industrial Research, Applied Biochemistry Division.

${ }^{b}$ Patel, J. J. Patel (unpublished data from a survey of bacteriophage host specificity involving five phage races and 270 Rhizobium strains); Pankhurst, C. D. Pankhurst, unpublished data on the responses of 24 Rhizobium strains in 28 physiological tests.

$28^{\circ} \mathrm{C}$ on yeast mannitol agar is inhibited by $3 \%$ $\mathrm{NaCl}$ and by $\mathrm{pH}$ values of less than 4.0 or more than 10.0. On Vincent medium without mannitol, all strains utilize one or more of the following carbohydrates and form acidic end products: glucose, galactose, fructose, arabinose, xylose, rhamnose, maltose, sucrose, lactose, trehalose, raffinose, mannitol, and dulcitol.

The electrophoretic patterns of the soluble proteins from strains of fast-growing Lotus rhizobia are similar to one another and are distinguishable from those of other species of fastgrowing rhizobia.

All strains produce extracellular polysaccharides which contain uronic acid, galactose, and glucose. Somatic antigens are highly strain specific, but internal antigens show a reaction of identity between strains and can be used to distinguish $R$. loti from slow-growing Lotus rhizobia and from other Rhizobium nomenspecies.

Cells can be infected by bacteriophages belonging to Bradley morphological types $\mathrm{B}$ and $\mathrm{C}$ (3). These phages are host range specific, and susceptibility to $\phi 2037 / 1$ may be used to distinguish $R$. loti from slow-growing Lotus rhizobia and from other Rhizobium nomenspecies.

The guanine-plus-cytosine content of the DNA of $R$. loti is 59 to $64 \mathrm{~mol} \%$. DNA-DNA hybridizations with reference DNAs from $R$. trifolii strain CC275e (5 to 13\%; mean, 8\%), $R$. meliloti strain SU47 (5 to 15\%; mean, 10\%),
Rhizobium sp. strain CC811 from Lotus corniculatus (46 to $74 \%$; mean, $60 \%$ ), and Rhizobium sp. strain CC809a from Lotus maroccanus (32 to $59 \%$; mean, $47 \%$ ) indicate that $R$. loti can be clearly distinguished from other fast-growing rhizobia. Strains of rhizobia from a variety of other plants have similar genetic relationships, indicating that $R$. loti forms part of a larger group of root nodule bacteria.

Nitrogen-fixing (effective) nodules are normally formed on the roots of Lotus corniculatus (bird's-foot trefoil), Lotus tenuis (slender bird'sfoot trefoil), Lupinus densiflorus (lupine), and Anthyllis vulneraria (kidney vetch). A few strains nodulate effectively on Lotus pedunculatus (Lotus uliginosus; big trefoil) or Leucaena leucocephala. Ineffective nodules may be formed on Lotus pedunculatus (Lotus uliginosus), Lotus angustissimus (narrow-leaved Lotus), Leucaena leucocephala, Clianthus punicens (red kowhai), Acacia sophorea (Acacia longifolia; sallow wattle), Carmichaelia angustata (large-flowered broom), Phaseolus vulgaris (kidney bean), Macroptilium atropurpureum (siratro), and Ornithopus sativus (serradella).

The type strain of $R$. loti is NZP 2213, a culture of which has been deposited in the American Type Culture Collection under the number ATCC 33669. This strain conforms to the description given above for the species with respect to morphology, physiology, antigenic 
relationships, and plant specificity. It is lysed by bacteriophages 1 through 7 of the 2037 series and by $\phi 2205$ but not by any bacteriophage from slow-growing Lotus rhizobia (26). The percent DNA-DNA homologies with $R$. trifolii $\mathrm{CC} 275 \mathrm{e}$, $R$. meliloti SU47, $R$. loti CC811, and $R$. loti CC809a are $10,5,60$, and $47 \%$, respectively. Nitrogen-fixing nodules are formed on the roots of the following plants: Lotus corniculatus, Lotus tenuis, Lotus japonicus, Lotus krylovii, Lotus filicalius, and Lotus schoelleri. Nodules which cannot fix nitrogen are formed on Lotus pedunculatus, Lotus hispidus (Lotus suavedens), and Lotus angustissimus.

\section{REPRINT REQUESTS}

Address reprint requests to: Dr. B. D. W. Jarvis, Department of Microbiology and Genetics, Massey University, Palmerston North, New Zealand.

\section{LITERATURE CITED}

1. Abdel-Chaffar, A. S., and H. L. Jensen. 1966. The rhizobia of Lupinus densifforus Benth., with some remarks on the classification of root nodule bacteria. Arch. Microbiol. 54:393-405.

2. Bailey, R. W., R. M. Greenwood, and A. Craig. 1971. Extracellular polysaccharides of Rhizobium strains associated with Lotus species. J. Gen. Microbiol. 65:315-324.

3. Bradley, D. E. 1967 . Ultrastructure of bacteriophages and bacteriocins. Bacteriol. Rev. 31:230-314.

4. Brewin, N. J., J. E. Beringer, and A. W. B. Johnston. 1980. Plasmid-mediated transfer of host-range specificity between two strains of Rhizobium leguminosarum. J. Gen. Microbiol. 120:413-420.

5. Brockwell, J., S. K. Asuo, and G. A. Rea. 1966. Acid production by rhizobia from the genera Trifolium and Lotus. J. Aust. Inst. Agric. Sci. 32:295-297.

6. Buchanan-Wollaston, A. V., J. E. Beringer, N. J. Brewin, P. R. Hirsch, and A. W. B. Johnston. 1980. Isolation of symbiotically defective mutants in Rhizobium leguminosarum by insertion of the transposon Tn5 into a transmissible plasmid. Mol. Gen. Genet. 178:185-190.

7. Craig, A. S., R. M. Greenwood, and K. I. Williamson. 1973. Ultrastructural inclusions of rhizobial bacteroids of Lotus nodules and their taxonomic significance. Arch. Microbiol. 89:23-32.

8. Crow, V. L., B. D. W. Jarvis, and R. M. Greenwood. 1981. Deoxyribonucleic acid homologies among acidproducing strains of Rhizobium. Int. J. Syst. Bacteriol. 31:152-172.

9. Dixon, R. O. D. 1969. Rhizobia, with particular reference to relationships with host plants. Annu. Rev. Microbiol. 23:137-158.

10. Erdman, L. W., and U. M. Means. 1949. Strains of Rhizobium effective on the trefoils Lotus corniculatus and Lotus uliginosus. Soil Sci. Soc. Am. Proc. 14:170-175.

11. Graham, P. H. 1976. Identification and classification of root nodule bacteria, p. 99-112. In P. S. Nutman (ed.), Symbiotic nitrogen fixation in plants. Cambridge University Press, London.

12. Jarvis, B. D. W., T. S. MacLean, I. G. C. Robinson, and G. R. Fanning. 1977. Phenetic similarity and DNA base sequence homology of root nodule bacteria from New Zealand native legumes and Rhizobium strains from agricultural plants. N.Z. J. Agric. Res. 20:235-248.
13. Jensen, H. L. 1967. Mutual host plant relationships in two groups of legume root nodule bacteria (Rhizobium spp.). Arch. Microbiol. 59:174-179.

14. Jensen, H. L., and A. L. Hansen. 1968. Observations on host plant relations in root nodule bacteria of the LotusAnthyllis and Lupinus-Ornithopus groups. Acta Agric. Scand. 18:135-142.

15. Jordan, D. C. 1982. Transfer of Rhizobium japonicum Buchanan 1980 to Bradyrhizobium gen. nov., a genus of slow-growing, root nodule bacteria from leguminous plants. Int. J. Syst. Bacteriol, 32:136-139.

16. Jordan, D. C., and O. N. Allen. 1974. Family III. Rhizobiaceae Conn, 1938, p. 261-264. In R. E. Buchanan and N. E. Gibbons (ed.), Bergey's manual of determinative bacteriology, 8th ed. The Williams \& Wilkins Co., Baltimore.

17. Martinez-de Drets, G., and A. Arias. 1972. Enzymatic basis for differentiation of Rhizobium into fast- and slowgrowing groups. J. Bacteriol. 109:467-470.

18. Martinez-de Drets, G., A. Arias, and M. Rovira de Cutinella. 1974. Fast- and slow-growing rhizobia: differences in sucrose utilization and invertase activity. Can. J. Microbiol. 20:605-609.

19. Murphy, P. M., and C. L. Masterson. 1970. Determination of multiple forms of esterases in Rhizobium by paper electrophoresis. J. Gen. Microbiol. 61:121-129.

20. Norris, N. O. 1965. Acid production by Rhizobium a unifying concept. Plant Soil 22:143-166.

21. Nuti, M. P., A. A. Lepidi, R. K. Prakash, R. A. Schilperoot, and F. C. Cannon. 1979. Evidence for nitrogen fixation (nif) genes on indigenous Rhizobium plasmids. Nature (London) 282:533-535.

22. Pankhurst, C. E. 1977. Symbiotic effectiveness of antibiotic-resistant mutants of fast- and slow-growing strains of Rhizobium nodulating Lotus species. Can. J. Microbiol. 23:1026-1033.

23. Pankhurst, C. E. 1979. Some antigenic properties of cultured cell and bacteroid forms of fast- and slow-growing strains of Lotus rhizobia. Microbios 24:19-28.

24. Pankhurst, C. E., and D. R. Biggs. 1980. Sensitivity of Rhizobium to selected isoflavonoids. Can. J. Microbiol. 26:542-545.

25. Pankhurst, C. E., and W. T. Jones. 1979. Effectiveness of Lotus root nodules. II. Relationship between root nodule effectiveness and in vitro sensitivity of fast-growing Lotus rhizobia to flavolans. J. Exp. Bot. 30:1095-1107.

26. Patel, J. J. 1976. Morphology and host range of virulent phages of Lotus rhizobia. Can. J. Microbiol. 22:204-212.

27. Peterson, P. J., R. M. Greenwood, G. B. Belling, and N. O. Bathhurst. 1971. The electrophoretic movement of soluble proteins and the production of unusual amino acids in Rhizobium isolates as taxonomic criteria. Plant Soil, p. 111-114.

28. Roberts, G. P., W. T. Leps, L. E. Silver, and W. J. Brill. 1980. Use of two-dimensional polyacrylamide gel electrophoresis to identify and classify Rhizobium strains. Appl Environ. Microbiol. 39:414-422.

29. Spitzbarth, M., A. Puhler, and W. Heumann. 1979. Characterization of plasmids isolated from Rhizobium meliloti. Arch. Microbiol. 121:1-7.

30. Vincent, J. M. 1970. A manual for the practical study of root nodule bacteria. Blackwell Scientific Publications, Oxford.

31. Vincent, J. M. 1977. Rhizobium: general microbiology, p. 277-366. In R. W. F. Hardy and W. S. Silver (ed.), A treatise on dinitrogen fixation, Sect. 3. Biology. John Wiley \& Sons, Inc., New York.

32. Vincent, J. M., and B. Humphrey. 1970. Taxonomically significant group antigens in Rhizobium. J. Gen. Microbiol. 63:379-382. 